\title{
The DebTOR-Friendly Fallacy in Business Rescue: AgenCy THEORY MODERATION AND QUASI RELATIONSHIPS
}

\author{
Marius Pretorius \\ Department of Business Management, University of Pretoria \\ Accepted: April 2016
}

\begin{abstract}
Tension often arises when Chapter 6 business rescue practitioners (BRPs) are appointed by directors to rescue their distressed businesses. Regulating by means of standard agency contracting becomes irrelevant in the resulting multiple relationships. Looking through the agency lens, using analytic autoethnography and compiling narratives, this paper explains the perceptions of what appear to be quasiagency relationships and obtains a better understanding of these. The findings suggest that the apparent principal-agent relationships suffer from asymmetries of goals, information access, informal power and diverging perceptions of moral hazard, transaction costs and adverse selection. As a solution, contracting has been shown to have limited value owing to outcome uncertainty and measurability. This is because the tasks of the BRP are non-programmable and term-dependent. The findings provide filing directors, shareholders, creditors, regulatory authorities and BRPs in this newly instituted regime, with enhanced understanding of how the relationships manifest in practice and overcome the non-contractibility of the newly formed relationships.
\end{abstract}

Key words: business rescue, conflict, turnaround, agency dilemma, auto-ethnography

JEL: D74, 23:

\section{Introduction}

Meet John and Jane. Last week they were the decision-makers in their seven-year-old business, with a turnover of R10 million $(\$ 1=R 15.5)$ per year. They believed that their business was viable and had recently appointed a new manager. Today they are the powerless audience for a business rescue practitioner (BRP) who is controlling their business and making "illogical" decisions. It seems, in this nightmare, that they are going to lose everything they have worked for so hard. How could this have happened? This is their story as participants in a show that they are now watching from the sidelines, powerless to intervene.

When both their lawyer and their accountant proposed business rescue as an option for addressing the financial distress of their business, this is not what they had understood the process would be like. "Filing voluntarily for business rescue under the new Act will protect the business from uncooperative creditors till you can solve the problem", is what they were told; now this has turned out to be an empty promise. They had understood the process to be: File for rescue with the Regulator through the prescribed process, appoint a BRP (expert), obtain the moratorium as protection under the Act and let the BRP sort out the problem. There was a prescribed hourly fee for this. It had been fourteen days since they started the process. The lawyer drove the prescribed filing process while they searched for a BRP. This turned out to be a somewhat chaotic process. How could they know whether the BRP they had chosen would have the relevant competencies? What options did they have other than to search marketing brochures and websites, investigate reputations and follow up on various references from their accountant and lawyer networks? The list of over 200 licensed BRPs provided by the Regulator contributed little information and actually added to a data overload, hampering their choice.

After shortlisting three possible candidates, interviewing each one and scrutinising the different contractual agreements they proposed, the five-day time pressure from filing to appointment forced them to make a quick choice of BRP. The decision as to whom to choose 
was finally swayed by a BRP with hourly fees lower than those prescribed by the Act, rather than opting for a staged success fee. This would mean that the BRP would present the plan after saving the business. The successful candidate professed that he wanted to save their business and protect their interests and employees optimally. Basing his statement on his experience, he was certain there was a reasonable prospect of saving the business if they acted quickly.

After the licence was granted to the BRP by the Regulator, John and Jane underwent severe interrogation from the BRP and his staff, during which they disclosed everything while fending off severe demands from creditors. They attended the first creditors' meeting, where it dawned on them what had really happened to them. When they reflected on some of the statements the BRP had made to the creditors, such as: 'I (as the BRP) have taken full control of the bank account and operations and will make all the decisions. I believe that there is a reasonable prospect of overturning the damage done by management (who now report to me) and saving the business. However, if this does not work out, there should be a better return obtained for creditors and shareholders than during liquidation.

John and Jane's disillusionment about the process and the future of their business reached a new low when they left the meeting. Even after contracting with the BRP, they now realised they had none of the "powers" they believed they had captured in the contract.

The complexity of the above narrative may appear chaotic to insiders and outsiders alike, probably because of the liability of newness of the business rescue regime. What appeared to be legislation to assist debtors and protect employees and the economy seems not to have materialised. Conflict among the debtors, creditors, practitioners and affected parties is the order of the day. Given all this, how should John and Jane proceed?

A Chinese proverb states: If you must play, decide on three things at the start: the rules of the game, the stakes and the quitting time. Directors who file "voluntarily" for business rescue in their businesses have to specifically understand the effect of the legislation (which constitutes the rules of the game) on their rights (stakes). Creditors seem to understand the rules and stakes very clearly, while the Regulator (CIPC) has a specific interest in the practical consequences for the rescue regime, as unintended consequences may signal a quitting time (revision of the act). BRPs have to choose whether they still want to play once they understand that the standard agency theory is rendered irrelevant owing to a change in the rules of the game (legislation). This paper aims to understand more fully how the legislation moderates the resulting relationships. I look through the lens of "agency theory" (explored later) to explain the various actor dynamics.

Section 129(1)a in Chapter 6 of the Companies Act 71 (2008) in South Africa (hereafter the "Act") obliges directors of businesses to file for business rescue proceedings when their companies experience financial distress. BR Portal (2013) reported the reputation of business rescue as being a regime acting as a critical scenario driver, as it appears to dictate the overall rescue industry's future. Currently, the industry is tainted with conflict and allegations of abuse and a high number of rescues that end in protracted court battles. Weyers and Elliot (2014) report on the associated abuse in the BR legislation, which adds to the conflict. Appointing someone (believed to be "your" agent) to lead the rescue of a distressed venture, is, therefore, an immensely important decision. Accordingly, practice shows high levels of conflict between BRPs and creditors about goals, interests, incentives, neglect, processes, outcomes, fees and costs. It appears that the elements of agency relationships do exist, but they are uniquely modified when entering formal business rescue to render several quasi-agency relationships. This study aims to investigate how these elements manifest in practice and the associated consequences, in line with the call by Thrahms, Ndofor and Sirmon (2013) for future research into agency relationships in turnaround situations. This paper expands the existing theory (Colquit \& Zapata-Phelan, 2007) on the agency relationships by demonstrating how legislation moderates their manifestation in practice.

The paper also briefly summarises the relevant aspects of the new Act and its dictated obligations and rights to the affected persons involved. Secondly, it reports concisely on the 
relevant key aspects associated with the agency phenomenon as generally known and understood, in order to use it as a framework (lens) for the research analysis. It focuses on what is manifested in practice and does not seek compliance with the legal aspects and correctness associated with Chapter 6. It then presents the researcher's role as that of observer-participant within analytic autoethnography as the research methodology. Fourthly, using the agency lens, it describes three "quasi" agency relationships brought about by the legislation. It then presents a framework that describes the development of the subsequent dominant relationship and thereafter reports the consequences with narratives and a comparative outlay of the elements. Finally, the paper presents the underlying boundary conditions for how the relations manifest in practice and describes why contracting is not a solution for addressing the associated conflict.

\section{Research questions}

Currently, the CIPC, as regulator of the rescue industry, is inundated with complaints about each other from directors, creditors and BRPs. Interviews conducted with parties affected directed the researcher to investigate the agency relationship as it manifests under the business rescue regime. The associated conflict in the relationship was used to gain insight into the practical manifestation of the relationship.

The research questions are thus:

1) How are the agency relationships moderated during business rescue?

2) What are the consequences?

\section{Background of rescue, rescue practitioners and creditors}

This paper aims to address the practical problems in a young industry and to build theory for industry actors. This section briefly summarises for the reader the context of business rescue, introduces how conflict develops and contextualises the rescue industry. This leads to the research questions.

Under Chapter 6, business rescue prescribes specific obligations for directors, practitioners and creditors. The Act sets out complex obligations for these parties. While Chapter 6 does acknowledge, and indeed intends to address, the need to balance the interests of affected persons (Loubser, 2013), the practitioners are ultimately the executors of the process. Despite the guidelines in section $7(\mathrm{k})$, this execution is subject to the agency dilemma that exists while they are taking managerial and financial control (in practice) of the distressed business. Bradstreet, Pretorius and Mindlin (2014) confirm this when they state that the legislature, instead of dealing with these problems in the text of Chapter 6, has instead "dumped" them on the office of the practitioner, which means that the BRP and the Bank consequently become opposing parties. While the Act attempts to balance the relationship in the so-called "debtor friendly" regime, the practical power distribution has resulted in conflict becoming a reality and rescue success an uncertainty.

Applying the Act leads directly to the following interpretations relevant to the agency relationship:

- Directors are obliged to file for business rescue if the business experiences financial distress (S 128(1)f). One aspect of the prescribed voluntary filing process entails the selection of the BRP.

- After appointment and licensing, the BRP takes managerial (S 140(1)a) and financial control (in practice) of the business.

- The BRPs must provide for the efficient rescue and recovery of distressed companies .... (S $7(\mathrm{k})$, investigate the affairs and report their belief that there is a reasonable prospect of saving the business by reorganisation (S 141(1)). Alternatively, if a better return than immediate liquidation could be achieved, it should/could be pursued (S 128(1b)(iii)). If none of the above is possible, the BRP must file for liquidation (S 141(2a)(ii)). 
- Both reorganisation and better return options depend on a rescue plan that is presented to the creditors, requiring a supporting vote of at least 75 per cent (S 152(2)).

Bradstreet et al. (2014) report that

without the support of creditors, particularly where the bank is a majority or significant precommencement creditor holding security, any attempt by the practitioner to mediate between all the affected parties could become futile when such creditors lack faith in either the BRP or the procedure itself. It would, of course, be unreasonable to expect a creditor to have faith in a dubious business rescue application or BRP appointment, but when other affected persons, or particularly a debtor company, makes a bona fide rescue attempt, it would be a shame for uncertainty to be the impediment to creditor co-operation.

Creditors are categorized with affected persons, including shareholders, employees and unions (S 128(1)(a)), with a voting interest (S128(1)(j). This vote gives creditors the power to support (or not) the rescue plan compiled by the BRP (Snyman-Van Deventer \& Jacobs, 2014). The powers associated with this vote have proved to contribute to the conflict between BRPs and banks. This conflict in the various agency relationships is explored in the next section.

\subsection{Agency theory}

Agency theory (also known as the principal-agent dilemma) is an established theory and has been a dominant paradigm since the 1990s (Hill \& Jones, 1992). It is briefly described in this paper as benefitting the uninformed reader. An agency relationship is a contract whereby one or more persons (principals) engage another person (agent) to perform some service on their behalf, which may involve delegating some decision-making authority to the agent (Jensen \& Meckling, 1976). A relationship, which could be a contract, is constituted as a result. Agency theory added the "Agency problem", which occurs when seemingly cooperating parties to the relationship have different goals and different divisions of labour (Eisenhardt, 1989; Kulik, 2005).

Agency theory is maintained by three underlying assumptions. First, people are selfish, have restricted rationality and are risk-averse. Secondly, there are goal conflicts among the stakeholders of the organisation. Finally, information is a commodity which can be purchased (Eisenhardt, 1989; Mehrotra, 2011. If both parties are utility maximisers, there is good reason to believe that an agent will not always act in the best interests of the principal (Jensen \& Meckling, 1976), Lui, 2011). Agency theory, therefore, suggests the potential for "mischief" when the interests of the principals and agents differ (Nyberg, Fulmer, Gerhart \& Carpenter, 2010; Lui 2011). It is this mischief that requires better understanding.

The cornerstone of the agency problem is the assumption that the interests of the principal and the agent diverge (Hill \& Jones, 1992). While contracting is the way to address the divergence, conflict in such relationships persists, even in the face of the contracting. Fundamentally, the conflict arises from self-interested behaviour, bounded rationality and risk-aversion (Eisenhardt, 1989), which underlie human assumptions, resulting in goal conflict. It appears that, in the business rescue context, the agency dilemma arises uniquely, despite the legislative obligations on parties to the relationship, as will be explored later.

Agency theory attempts to address two main problems: the conflicting goals of the principals and the agents and the difficulty for the principal in verifying or authenticating the agent's actions (Eisenhardt, 1989). This was demonstrated by John and Jane's perceptions as discussed in the introduction. The Agency problems occur because the agent is not risk-neutral (Mehrotra, 2011). Imperfect information (hidden action) and misaligned incentives (hidden information) result in the fear that agents may pursue their own interests (Lui, 2011). Hence, in the face of the risks which agents face, there will be conflicting desires and it will be difficult to verify the agent's actions in the light of whether they were in the best interests of the company. The principal-agent theory is useful for determining the most efficient contracts for aligning the interests of both the principals and the agents (Lui, 2011). Agency theory is therefore the chosen lens through which all the relationships in this paper are judged. 
The agency problem of inducing the "agent" to behave as if he were maximising the "principal's" welfare, is quite general. It exists in all organisations and in all cooperative efforts (Jensen \& Meckling, 1976). It contains two elements: moral hazard and adverse selection. Moral hazard is the choice taken by an agent to pursue the needs of the principal. The agent has the resources, the information and the powers to do so, but chooses against this for various reasons, which originate from divergent goals. Adverse selection means that the principal does not have the financial resources, information or knowledge to screen the agent before appointment, despite wishing to do so. The principal faces this risk, and throughout the vetting process needs to assess the agent's ability to execute the contract.

The literature (dominated by articles from 1970-1990) demonstrates the core conflict characteristics/issues associated with principal-agent relationships, including: goal difference, risk orientation (seeking vs aversion), information asymmetry, adverse selection, moral hazard, information systems and incentive types (outcome vs behaviour-based contracts). Contextual issues of relevance that may moderate the characteristics are part of the interest in this research, as it appears to render agency theory non-existent despite several of its aspects being apparent in the quasi relationships.

\subsection{The nature of agency conflict}

Conflict appears to be a natural by-product of agency relationships and leads to tension. In this paper, I use conflict in alignment with Webne-Behrman's (2009) definition, which refers to disagreement between parties that escalated to being perceived as a threat to the needs, interests and concerns of the parties. The key notion is that it is perception-based and underlies the existing tension.

\subsection{The dominant moderations to the apparent agency relationships under business rescue}

In a general agency relationship, the decision-making process is in the hands of the professional manager as agent, whose interests are not necessarily identical to those of the residual claimants (Fama \& Jensen, 1983). In business rescue, a BRP is obligated by the Act and is held accountable for all the decisions to be made in the organisation under rescue. Ownership is not transferred to the BRP, only custodianship. Hence, the separation of "ownership" and "control", more precisely, the separation of residual risk-bearing from the decision-making functions. The BRP, as officer of the court, makes the decisions but does not bear any direct financial risk in the event of the company closing down. The BRP has the functions of an agent but "being an agent" is questionable, considering the above role of the court.

Imperfect information generally arises for the appointed agent because the Act requires independence (S 138) from previous involvement with the filing company. The directors (who believe themselves the principal) who file have full information. The bank, which has the powers of a principal, and which has a history with the company, has information (but of a different nature), while the BRP has little information and is tasked by the Act (S 141) with investigating the affairs of the company. General conflict, which results from the relationships, gives rise to the non-sharing of information, so there is imperfect information or information asymmetry.

The term transaction costs in business rescue generally refers to the fees of the BRP, the incentives, the direct costs in the execution of duties, the cost of expert investigators used and the specialist advisor costs, such as legal contingencies. The BRP's costs take priority over the claims of all the secured and unsecured creditors (S 141 (2)(a)) if reorganisation/rescue fails and the end result is liquidation. Thus, in the event of the company being liquidated, the BRP's costs are paid first. BRPs do face reputational risk in the event of disagreements and potential objection and removal by any "affected person" under section 130. This may result in the loss of future appointments. Failure to implement the proposed rescue plan may further tarnish relationships with key players in the industry, such as revenue services, banks, suppliers, customers and 
investors, among others. In terms of the separation of ownership and control, the agency problem is controlled by decision systems that separate management (initiation and implementation) and control (ratification and monitoring) of important decisions at all levels of the organisations, in line with Fama and Jensen (1983). How do the principals (who, in practice are really the banks as creditors and not the appointing directors) control the agency problem in the business rescue scenario?

\section{Moderation effects}

A moderator, in this text, refers to the presence of a factor or a moderating condition that alters the relationships between elements when it is present or introduced. Moderating effects refer to the variation in outcomes (directional deviations) of the elements as a result of the presence of the moderator. Such effects on the elements include a variation in importance, relevance and manifestation under the introduced condition. Such variations bring about various consequences for the environment.

Classic agency relationships exist at different levels in businesses that perform well, such as a healthy going concern. A 'new' Act came into effect in 2011, which is the moderator / moderating condition in this study. Once a business has filed for rescue under the Act, the presence of the moderating conditions alters the relationships between variables (the elements of the classic agency relationship). Moderating effects can be observed in how the elements respond to the presence of the moderator. In this instance, the focus is on goal conflict, information asymmetry and systems, risk approach, adverse selection, moral hazard and transaction costs.

\section{Research methodology}

Table 1 explains the research design in a summarised format, followed by an extensively detailed first person account of the execution of the analytic auto-ethnographic (AAE) study.

Table 1

Research design components based on the adapted design description by Yin (2003)

\begin{tabular}{|c|c|}
\hline Component & Description \\
\hline Problem & $\begin{array}{l}\text { When directors (as principal) voluntarily file for business rescue, they practically lose total control } \\
\text { of their business to the BRP and ultimately the creditors. They end up with little or none of the } \\
\text { expected benefits when they filed. Tension within the altered agency relationship develops during } \\
\text { business rescue. It appears that the "standard" agency relation is modified as a result of } \\
\text { legislative obligations. }\end{array}$ \\
\hline Research questions & $\begin{array}{l}\text { How are the agency relationships moderated? } \\
\text { With what consequences? }\end{array}$ \\
\hline Research aim & $\begin{array}{l}\text { To better understand the interrelations and level for action created by the moderating effect of the } \\
\text { legislation. Agency theory is the lens for the investigation. }\end{array}$ \\
\hline Context & Business rescue regime that is young and developing. \\
\hline Propositions* & 1.The agency relationship is fundamentally moderated under business rescue legislation. \\
\hline Phenomena investigated & $\begin{array}{l}\text { Primary - Agency and perceived agency relationships. } \\
\text { Secondary_Issues/elements associated with the manifested relationships. }\end{array}$ \\
\hline Unit of observation & $\begin{array}{l}\text { Industry role players, including directors, BRPs, bankers working with business rescue in their } \\
\text { organisations and affected persons. }\end{array}$ \\
\hline Methodology & Analytic auto-ethnography. \\
\hline $\begin{array}{l}\text { Logic linking the data to the } \\
\text { propositions }\end{array}$ & $\begin{array}{l}\text { BRPs and bankers are the determining agents and principals in the practice relationship under } \\
\text { the Act. Their conscious and unconscious cognitive arguments/motives to pursue their goals can } \\
\text { inform how the new relationships unravel. Making sense of their lived experiences could lead to a } \\
\text { conceptual framework for understanding how the agency relationship is moderated in the } \\
\text { business rescue context. If contracting is not a viable solution to this relationship, alternatives can } \\
\text { be proposed. }\end{array}$ \\
\hline $\begin{array}{l}\text { Criteria for interpreting the } \\
\text { findings }\end{array}$ & $\begin{array}{l}\text { Differences from and/or manifestations of the agency dilemma as reported in the mainstream } \\
\text { literature. }\end{array}$ \\
\hline
\end{tabular}




\section{Context of the research}

The project started with action research, as it addresses a practical problem triggered by conflict within the industry. As I wanted to make sense of the lived experiences of actors, I used my own turnaround experiences and previous research and applied analytic auto-ethnography. I wanted to make sense (Berniker \& McNabb, 2011) of moderating effects and to propose a framework that may lead to guidelines for role players. This therefore involves description (of issues) and understanding (causality), but mainly sense-making and interpreting the multiple narratives describing the experiences. Table 1 condenses the thinking underlying the research.

I chose a multiple-source setting, because it accumulates extreme contributions from various contexts and examining these extremes may be helpful, because reasons for differences often only become clear under extremes/under extreme conditions (McClelland, 1998). The unique qualities of this industry make this setting ideal for direct theory building (Yin, 2003), "because the dynamics being examined tend to be more visible than they might be in other contexts" (Pratt, Rockmann \& Kaufmann, 2006).

\section{$7 \quad$ Researcher qualities}

In analytic auto-ethnography, the researcher plays a dominant role. Therefore, in attempting to answer the research questions, I was aware of my own methodological values, beliefs and philosophical assumptions. These assumptions could influence how the research was conducted and are stated in order to understand the 'intellectual climate' in which the research was conducted. The theory of knowledge (epistemology) of a researcher describes how one can discover underlying principles about social phenomena and how one can demonstrate knowledge. From my personal experience with critiquing strategies for businesses and taking the role of devil's advocate when doing so, the research process emerged naturally. During the research, I was further influenced by the role that I have come to play as a strategy consultant when facilitating strategic critiques and analyses to guide company boards and management: that of the "devil's advocate". Being the devil's advocate depends heavily on challenging conventional thinking, assumptions, reasoning, accepted principles and rules. I do this deliberately by applying $\mathrm{AAE}$ as a technique. The end result of such a process is often a framework that depicts the key issues that integrate the context and the problem addressed. I therefore applied the same reasoning to understand and interpret the moderating effects when I identified them. It is important to clarify that I have an informal agreement with the Regulator not to apply for a BRP license in order to maintain independence in the industry, which allows for neutral research, such as the industry status quo report (Pretorius, 2015).

At the same time, as an academic and experienced turnaround consultant, I have a preference for factual directives. To mitigate my biases and subjectivity, an AAE in the interpretivist philosophy was applied to capture the issues, perceptions and experiences after systematic reflection on each of the "actor cases" to establish the moderating effects resulting from the legislation.

A researcher's ontological position comprises his/her view on the very nature and essence of the research reality. I am an objective realist who believes that knowledge comes from the facts associated with real-life cases and their context. Thus, proper research methodology is crucial for eliciting insight from such facts. As a positivist who is forced by the context of my research field to conduct qualitative research, I embarked on this research design with caution, focusing on delivering trustworthiness. While every individual element may be unique within its own context, when I found repeated appearances of issues and relationships covering the cases, I could "generalise" from them. My interest was mainly in identifying directives to guide those who depend on my opinion as a researcher in business rescue.

\subsection{Data collection procedures}

I recently completed research for the Regulator on the state of the rescue industry. It involved interviews with BRPs, banks, directors who filed, academics working in rescue, staff of the 
Regulator, lawyers and accountants working in the field. I also held a public workshop and ran three different surveys. I considered the issues in general and then those relevant to specific cases of individual subjects, making conceptual notes that I captured on an Ipad because of its quick and easy accessibility. Like Dyson (2007), I sought new understandings rather than the truth only.

\section{Analytic auto-ethnography (AAE) and data collection}

I pursue an analytic auto-ethnographical approach (Fine, Morrilli \& Surianarain, 2009). Anderson (2006) identifies five key features of AAE and I follow closely the process described by Venter and de Villiers (2013):

Firstly, "complete member researcher" status; in other words, the researcher is a complete part of the social world under study (Anderson, 2006). Specifically, membership of a particular social group precedes the decision to conduct research on the group. I was involved with turnarounds in various forms for over 20 years before starting this study. The catalyst for the study was the unprecedented number of requests for advice from role players for my "independent" opinion as an academic researcher. I realised from my own perspectives that I should "take stock" of what is happening. This allowed me not only to record events I had experienced and conversations in which I had participated since becoming sensitised, but also to reflect on ongoing events. I spent a period of approximately two years, starting in October 2011, collecting data as an analytic ethnographer. This included observations from my day-to-day experiences, as well as the collection and analysis of a number of conversations ranging from informal to formal. In terms of the four categories of observer described by Gold (1958), namely complete participant, participant-as-observer, observer-as-participant, or complete observer, I can best be described as an observer-participant.

Secondly, AAE is characterised by analytic reflexivity. As an observer member researcher, as opposed to an ordinary participant observer, a researcher has more interest in the beliefs, values and actions of other participants (Anderson, 2006). In fact, "auto-ethnographic interrogation of self and other may transform the researcher's own beliefs, actions and sense of self" (Anderson, 2006). I found this to be true in this case. While I was immersed in the sense-making process, my role as auto-ethnographer transformed my views of my perceived status quo. During the process, as the observer participant, I became increasingly aware of the lived sensitivities of participants in the rescue process. This also led to occasional role conflict (observer versus consultant), but, as an academic, I had to continue. This process led me as observer-participant to gain a sense of perspective and additional data and insight.

Thirdly, it is acknowledged that AAE takes into consideration that the researcher's own feelings and experiences would be incorporated into the text and are considered to be important data for understanding the social phenomenon under review (Anderson, 2006). Such a process should be devoid of "self-absorbed digression" (Anderson, 2006) and it is imperative that an autoethnographer engages with others in the social worlds they are trying to understand. The fact that I was enacting participant and researcher (observer) roles, fostered helpful and unique perspectives. In addition, I compared the data and findings during interviews, with formal research results (Pretorius, 2014b).

Fourthly, AAE is based on dialogue with informants beyond the self in order to guard against "self-absorption" (Anderson, 2006). Analytic auto-ethnography is based on self-experienced evidence, but it also reaches beyond it. In this regard, Anderson (2006) argues that in-depth interviews are a useful tool. As an additional step, once I had gained preliminary insights for the framework, I tested its elements by means of structured questionnaires (descriptive) during the workshops, as well as those of my Masters and PhD students. During this phase of the data collection, I took on the role of observer.

The triangulated data sources and research design increased the trustworthiness and credibility of the research, because it enabled checking and rechecking the data and analysis among several different sources (own observations and insights, interviews and surveys) (Yin, 2003). Thus, I was 
able to mitigate tendencies towards fundamental attribution error, inherent cultural prejudice and self-fabrication (Woodside, 2010).

Finally, AAE calls for a commitment to an analytic agenda. Anderson (2006) uses the word analytic "to point to a broad set of data-transcending practices that are directed towards theoretical development, refinement, and extension". This distinguishes analytic auto-ethnography from evocative ethnography or first-person narrative. In this paper, my own observations on the moderating effects lead to a better understanding of broader social phenomena elucidated through institutional theory.

\subsection{Data analysis}

Once the elements had been identified, I converted them into the three narratives. The appointing director narrative (John and Jane) has already been offered in the introduction. Thereafter, the elements were structured in a framework. Elements were framed as a diagram depicting role allocation during the process of business rescue (see Figure 1). Table 2 reports the analysis outcome and describes how the elements relevant to agency relationships differ for the perceived principals and agents.

The research style was initially exploratory but also explanatory, to identify and describe the issues and how legislation moderated them. Eventually, after understanding how components relate and to make sense of the issues, I then asked a senior practitioner with banking experience and a Regulator official to read the narratives and confirm their accuracy. This served as "member checking”.

\section{Findings}

Writing the actor narratives allowed me to include and express the most recent and urgent issues that came to my attention. Seminal issues that repeatedly surfaced became readily visible. The quotations used in the narratives are from the subjects and are used to enrich the trustworthiness of their lived experiences. I could write from an unbiased perspective with a neutral stance as I had heard all sides of the story and was impartial. This allowed for reporting the lived experiences in real time. In this section, I first extend the narrative of John and Jane, who appointed the BRP. Next, I present the narratives of apparent principals and the agent as perceived in practice. This addition completes the triad of key actors in business rescue. Thereafter, I describe the moderated agency relationships framework (Figure 1) and present the different elements for the triad (Table 2).

\subsection{The directors' extended narrative}

Extending the opening narrative of John and Jane, the following can be added. Keeping in mind that Le Roux and Duncan (2013) had already reported that small business owners had limited knowledge of business rescue legislation. Their directors and shareholders alike are generally under pressure (from creditors and otherwise under the Act) when selecting or being advised to pursue voluntary rescue (S 129) and resolve to file. Their situation forces them to become risk seekers (Kahneman, 2011) when they file. Mostly, they believe (and hope) that there is a reasonable prospect of saving and reorganising the business in the face of the financial distress. At the same time, they believe that the BRP they select will pursue the rescue with consideration for their own interests and goals and, while they have several obligations, filing for business rescue effectively has stripped them of all their powers and rights (Gribnitz \& Appelbaum, 2014), to the extent that they have become an audience to their own "play". Often, on realising their status, they resort to covert tactics that oppose the actions of the BRP. In severe cases, where their previous actions (sometimes unlawful) are exposed, this often leads to deliberately undermining the efforts of the BRP. Within a short time, the BRP becomes the enemy of the directors and they blame him/her for being a "servant of the creditors" and even for being responsible for the demise of their business. 


\subsection{The practice (new) principal's narrative}

Meet Petra. She is the banker responsible for this account after rescue started. Someone else was the relationship manager as bank representative when they financed the business with a loan and contracted strict payment conditions as determined by the bank.

At the time of filing, we (banks) know that the business has gone past the point of no return unless new finance is granted, which we are reluctant to allow. We refer to it as the "first cut is the last cut", as we do not want to throw new (good) money after old (bad). Previous management could not address the business' problems, "so what makes the newly appointed BRP think s/he can do it anyway?" This will probably raise the bank's risk and exposure, thereby opposing our "goal and mandate". It all has to do with our overall institutional goals, which are associated with risk:return ratios (risk aversion). After all, "banks are businesses too". "BRPs therefore blame us (the banks) for being pro liquidation and entering the rescue with "predetermined goals".

The bank was therefore a loan principal to John and Jane (loan agents) during the pre-rescue period when they were not distressed, albeit it may have been only for a portion of the total loan capital. Bank contracts and securities are, for the most part, failure proof during this phase. John and Jane reported financial information within the confines of the debt contract, fulfilling the role of agent while their business was not in financial distress.

By virtue of the bank's historical involvement, the bank believes and argues that, when directors file, they (the banks) have already exhausted all the possible remedies (financial restructuring) for saving the distressed business, so the last resort for achieving solvency is to infuse post commencement finance.

Also, as banks appear to have unlimited resources, they prefer the legal route (legal orientation) to curb BRP actions, and are thus seen to be forcing the BRP into the "underdog" position, disempowering the agent's freedom in decision-making and "manipulating" the intended agent role.

As there is a large divide between the interpretation and determination of reasonable prospect, banks typically perceive the BRP's ability to navigate a successful reorganisation as suspect. They ask: "How long will he take to see there is no prospect?" This perception of incompetence is infused with the BRP's time constraints, access to information and so-called "calling" (hope) to rescue the business. Bankers specifically highlighted the BRP's inability to cooperate and communicate, along with an absence of empathy for the opposing view. This aggravates the perception of incompetence. Practice research shows that banks respond to early warning signals long before directors do and they institute measures (mainly financial restructuring) early in the decline. By the time BRPs are appointed, most of the avenues to accessing any potential "slack" in the form of free assets (Smith \& Graves, 2005) have often been exhausted.

The competence requirements for performing the navigation assignment of a BRP give some insight into the differences in perception between principals and agents. The BRP is required to determine the "best future position" for the distressed business to pursue. After investigating the affairs of the business, the BRP has to determine what this best future position is, include it in the rescue plan and obtain a majority vote $(75$ per cent + ) by the creditors. If there is disagreement on the reasonable prospect, this agreement is hardly possible and therefore seems to be at the heart of the conflict. No easy and generalizable measures to determine whether there are reasonable prospects of rescue are agreed on, as different banks and BRPs claim these as their potential competitive advantages. Unfortunately, at this point the BRP has been appointed and unless the bank is willing to spend resources, the BRP can be removed by means of a legal process (S 139).

Even if BRPs are not perceived as incompetent, subjects from banks suggested that the intention of the BRP is doubtful and questionable. If there is no prospect, the only possible reason for not pursuing liquidation must be that the BRPs are "writing fees" (incentives) for as long as they could. Bank subjects feel that BRPs know there is no prospect (because banks know it) but act unethically (moral hazard) in pursuing the so-called better return alternative allowed for in the 
Act. BRP remuneration (agency costs) is a contentious issue, as bank subjects indicate this to be the main malpractice by BRPs who extend prescribed periods in the process. The "longer the rescue goes on, the less the security of the banks is protected". BRP fees (remuneration) and costs incurred during rescue take priority over the secured claims in the eventual liquidation.

\subsection{The BRP as agent's narrative}

Meet Gerry. I only take rescues I think could work. The directors need my knowledge and expertise to pull this one off. Without me, they stand no chance, so my contract with them contains fees as prescribed, costs, consultant fees and a success fee. John and Jane know it was their poor decisions that got them into trouble, so if the company cannot afford it, they must foot the bills in their personal capacities. Anyway, I take financial control, so I "make the payments when I think it important".

The least of my problems as BRP is the directors; rather, the problem is the bank. The power of the banks is lopsided compared with that of the BRP, despite no contracting at any stage. Holding the voting power, banks close all the facilities immediately after filing or alter the conditions, such as factoring collections to benefit them - thus leaving us (the BRPS) "powerless without the cash to continue basic operations". If they advance any monies, "they consider it as post commencement finance (PCF), "thereby changing old credit to PCF, which has a higher priority in rescue. Banks renege on their promises and agreements about PCF and support. They do so by extending loan periods and altering recoveries to benefit "factoring". Cases have been reported in which banks renege on supporting the rescue plan as they arrive at the second creditors' meeting, despite supporting it during the negotiations.

The BRP knows that blaming the previous management (at the first creditors' meeting) for the distress assists him in appearing knowledgeable and gathering creditor support - one thing they have in common with the bank.

The BRP takes management control of the business on appointment and therefore becomes executor (agent) to the contract. The final decision-making rests with the BRP until voting for the rescue plan takes place. Despite this dominant position relative to the directors as "appointing" principal, the BRP "takes the underdog position" in the new agency relationship established with the practice principal, as the "banks are notified of new filings before anybody else". This information asymmetry benefits the bank, as it has access to critical financial information, which it does not share under the "excuse of confidential information protected by bank-client privilege". Thus, the BRP faces the liability of information "confidentiality". This further entrenches the practice principal in the power position.

Furthermore, "banks continuously demand information" from us while "they have more than we BRPs have" and it takes time to gather sufficient data to make a decision on the reasonable prospect. At the same time, we need to spend additional time answering their queries and are then blamed for "inflated fees".

BRPs believe that banks prefer liquidation, as it is "best for the bank's security". Alternatively, they want to see a rescue plan ensuring that their assets are protected. BRP subjects often maintain that "banks are over-secured most of the time" by a factor of three. Banks come to the creditor meetings and inform us that they will vote against the plan.

BRPs depend on their reputation for future appointments. They will therefore do almost anything to protect their "name in the industry". To pursue a better return than is found in liquidation as an alternative to reorganisation is an option that is easier to pursue and even incompetent BRPs can do so by pursuing simple extended debt restructuring plans or by selling assets similar to those in liquidation. Typically, this absence of a turnaround intention is negatively considered by the banks. Thus, bank subjects equate the choice to pursue better return rather than reorganisation with BRP incompetence and lack of turnaround intention, despite its being an alternative within the Act. This issue relates to BRPs being blamed for not performing at the required standard, which in itself is a vague issue. BRPs ask why this is so. 
Figure 1 depicts the comparative status changes of role players (perceived relationships) under the conditions brought about when Chapter 6 voluntary filing is affected. Three relationships of relevance for this study are affected. First, the initial director-bank relationship (can be multiple principals) that governed the loans before filing comes to an end. Secondly, the appointing directors-BRP (principal-agent) relationship changes to effectively eliminate the appointing directors from the relationship. Finally, the practice Creditor-BRP (principal-agent) relationship comes into existence. This specific relationship is the one that will drive the industry, as will be shown. The appointing director-BRP relationship is explained, but the focus of the remaining discussion will be on the practice principal-agent relationship.

Figure 1

Perceived agency relations that come into existence during the transition from a going concern to a business in rescue under Chapter 6 (Own compilation)

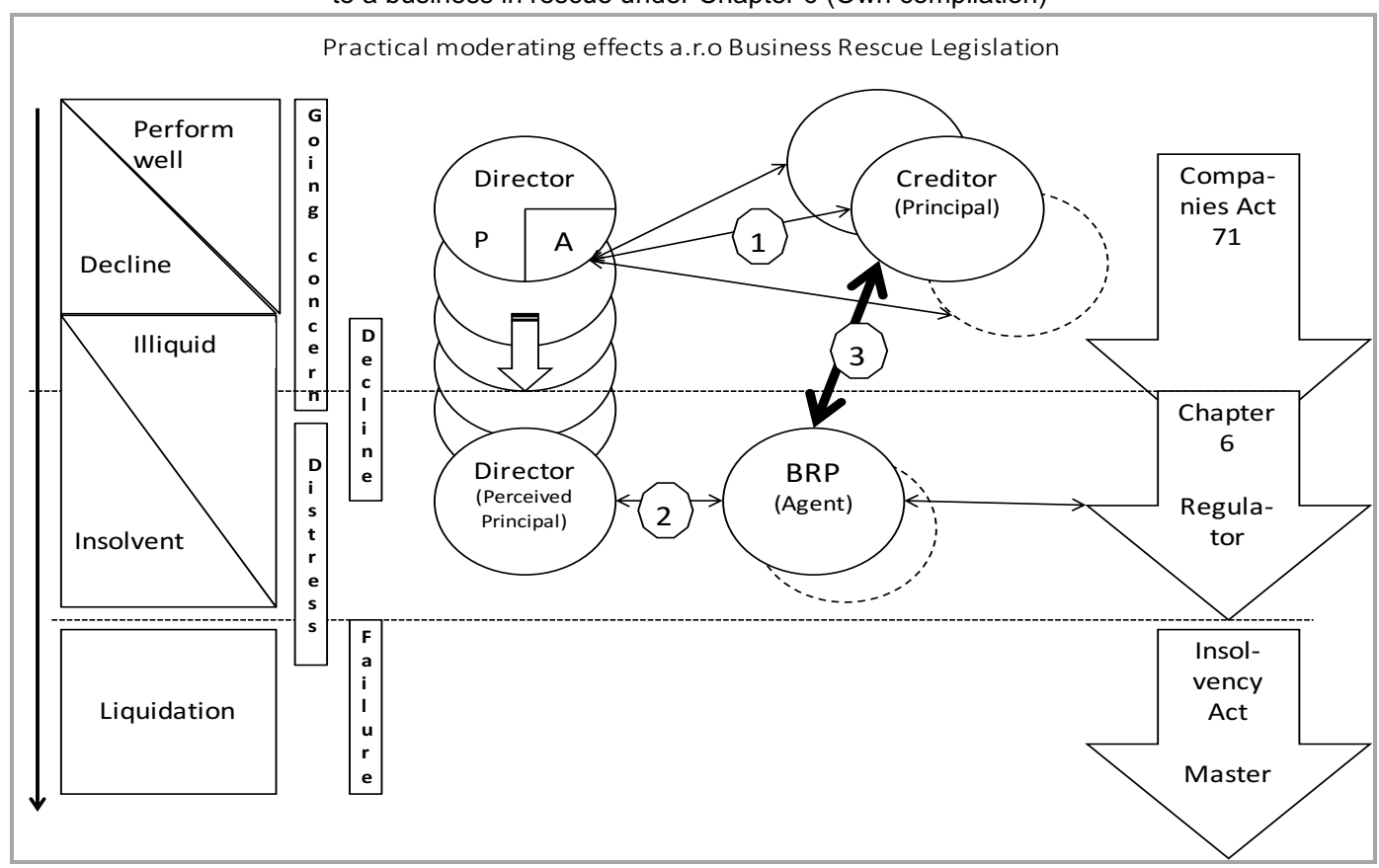

The directors (appointing principals) appoint the BRP (agent), who effectively brings an end to their rights and powers (unknown to them at the time) but not their obligations (Gribnitz \& Appelbaum, 2014). This effect is directly contradictory to that found in the US Chapter 11 debtorin-position situation, as the directors' roles become subject to that of the BRP in decision-making under Chapter 6 (Mindlin, 2013).

The practice principals (creditors and the banks) are given formal rights (over and above protection of their investment) by the Act (Gribnitz \& Appelbaum, 2014) to pursue their goals and informal powers (voting interests) to govern the BRP (inherited) and, specifically, the proposed rescue plan. The constructed narratives provide rich descriptions of the changes in and conflict points of the quasi agency relationships. Within each narrative, the quotations from the different subjects act to support the sense-making.

\subsection{The consequence of the moderating condition}

One key consequence of legislative change is the extensive conflict that initiated this research. Associated with this conflict, if not resolved, is declining trust, more blame, more opposition to the other party, installing systems to block opposing decisions, legal challenges and more, but the worst for the BRP is the lack of support at the vote. The banks are in a better position and growing 
in power during the process, as they have more resources than the distressed company has to pursue legal avenues. The consequences of the conflicts and actions are interwoven within the discussion of the findings that follows.

The quasi principal-agent relationship (between creditor and BRP) under Chapter 6 voluntary filing brought to light several additional complexities. First, the practice principal (banks as creditors) suffers total adverse selection, as the directors appoint the BRP. As creditors, they inherit the appointee and, while they can oppose the appointment by means of a court application (S 139), this seems to occur only irregularly and is both costly and time-consuming. It appears that banks take the decision not to cooperate if the BRP is considered weak. Second, by controlling all the financial access to short-term finance and PCF, the banks control the transaction costs associated with the agency relationship. This is a major factor contributing to the conflict. Third, despite the practice agent (BRP) being given many obligations and powers, a BRP's task of proposing a rescue plan for the vote is ultimately governed by the practice principal. Significant conflict underlies the opposing views between practice principals and agents, although, in the end, the agents appear powerless and subject to the narrow views and goal centrism of the practice principal.

Table 2 summarises the element manifestations for the appointing and practice principals, as well as for the agent after filing. It covers the elements (variables / characteristics) used to describe a classic agency relationship.

Table 2

Effects on agency perceptions in business rescue driving the conflict within the relationships

\begin{tabular}{|c|c|c|c|}
\hline Agency element & Directors & BRP & Bank \\
\hline $\begin{array}{l}\text { Perception in } \\
\text { practice }\end{array}$ & $\begin{array}{l}\text { Perceive / believe themselves to } \\
\text { be the principal by appointment. }\end{array}$ & Assume the role of agent & $\begin{array}{l}\text { Perceived to have the powers of a } \\
\text { principal in practice. }\end{array}$ \\
\hline $\begin{array}{l}\text { Goals, goal } \\
\text { difference / } \\
\text { expectation / conflict }\end{array}$ & $\begin{array}{l}\text { To save the business and own } \\
\text { capital (if shareholders). }\end{array}$ & $\begin{array}{l}\text { To successfully execute the } \\
\text { rescue and protect reputation } \\
\text { (future income stream). }\end{array}$ & $\begin{array}{l}\text { To protect the invested capital at } \\
\text { the lowest risk while remaining } \\
\text { "independent". }\end{array}$ \\
\hline Risk orientation & $\begin{array}{l}\text { Become risk-seeking when filing } \\
\text { in the face of adversity and } \\
\text { uncertainty (Kahneman, } \\
\text { 2011:315). }\end{array}$ & Risk averse to protect reputation. & $\begin{array}{l}\text { Risk averse to protect security. } \\
\text { Cannot be seen to be part of the } \\
\text { BR decision process other than } \\
\text { the vote. }\end{array}$ \\
\hline $\begin{array}{l}\text { Information } \\
\text { asymmetry }\end{array}$ & $\begin{array}{l}\text { Full information of the venture } \\
\text { distress but deficient on legal } \\
\text { process and consequences. } \\
\text { Potentially deficient on causality. }\end{array}$ & $\begin{array}{l}\text { Information deficient and largely } \\
\text { dependent on appointing } \\
\text { principal and own ability to } \\
\text { analyse and make sense. Suffers } \\
\text { time implication to investigate } \\
\text { properly. }\end{array}$ & $\begin{array}{l}\text { Historical, financial and managerial } \\
\text { behaviour information based on } \\
\text { banking verifiers (Pretorius \& } \\
\text { Holtzhauzen, 2013). Will exploit } \\
\text { the asymmetry to maximise own } \\
\text { interests. }\end{array}$ \\
\hline $\begin{array}{l}\text { Information systems } \\
\text { to authenticate the } \\
\text { agent actions }\end{array}$ & $\begin{array}{l}\text { Desperate need for control } \\
\text { system but unable to achieve } \\
\text { under Chapter } 6 \text { (see rights). }\end{array}$ & $\begin{array}{l}\text { Not supported, as it inhibits } \\
\text { autonomy. Prefer opposite. }\end{array}$ & $\begin{array}{l}\text { No need - has own verifier system } \\
\text { and historical records of } \\
\text { behaviour. Demand continuous } \\
\text { information from agent. }\end{array}$ \\
\hline Adverse selection & $\begin{array}{l}\text { Suffer from hidden information } \\
\text { about the agent (Shapiro, } \\
\text { 2005:243). }\end{array}$ & $\begin{array}{l}\text { Benefit from "despair" of } \\
\text { appointing principal. }\end{array}$ & $\begin{array}{l}\text { Inherit the agent from the } \\
\text { appointing principal actions } \\
\text { requiring high cost to reverse. }\end{array}$ \\
\hline Moral hazard & $\begin{array}{l}\text { Depend on it as only "useful" } \\
\text { contractual model. }\end{array}$ & $\begin{array}{l}\text { Depends on individual ethical } \\
\text { values. }\end{array}$ & $\begin{array}{l}\text { Assumes/expects the agent will do } \\
\text { the right thing. Reputation } \\
\text { determines bank support. }\end{array}$ \\
\hline $\begin{array}{l}\text { Transaction costs / } \\
\text { incentive }\end{array}$ & Agree to almost anything. & $\begin{array}{l}\text { Negotiates fee structure and } \\
\text { outcome (success) remuneration } \\
\text { - sometimes exorbitant. }\end{array}$ & $\begin{array}{l}\text { Opposes what is termed } \\
\text { "exorbitant costs". }\end{array}$ \\
\hline $\begin{array}{l}\text { Reason for entering } \\
\text { the exchange }\end{array}$ & $\begin{array}{l}\text { Held for use (Kahneman, } \\
\text { 2011:294). }\end{array}$ & $\begin{array}{l}\text { Held for exchange (Kahneman, } \\
\text { 2011:294). }\end{array}$ & Held for exchange. \\
\hline Goal centrism & $\begin{array}{l}\text { To protect business and personal } \\
\text { investment. }\end{array}$ & To completely successful rescue. & $\begin{array}{l}\text { To protect investment at lowest } \\
\text { risk. }\end{array}$ \\
\hline Reference point & Equity saving. & Success reputation. & Security protection. \\
\hline $\begin{array}{l}\text { Rights allocated in } \\
\text { Act }\end{array}$ & $\begin{array}{l}\text { No rights after filing (Gribnitz \& } \\
\text { Appelbaum, 2014). }\end{array}$ & 24 & 37 \\
\hline $\begin{array}{l}\text { Obligations } \\
\text { prescribed in Act }\end{array}$ & 206 & 583 & 7 \\
\hline Potential bias & Escalation of commitment. & & \\
\hline
\end{tabular}




\section{Discussion of findings, key theoretical components and insights from the study}

The research set out to understand more fully the moderating effects of the new legislation and explain its consequences for the industry, especially the Regulator but also the future principals and agents in practice. To enhance meaningful coverage of the findings, this section deliberates each aspect of the findings as they appeared during the analysis process and uses the elements of classic agency theory as its lens. The findings, the first in this field, are then elaborated and explored for improved understanding to guide the proposal of a framework for agency relationships that unfold in practice under business rescue.

\subsection{Boundary conditions created by the moderator}

Based on the differences described in Table 2, the moderating condition (when under business rescue in Chapter 6) is characterized by several drivers that influence the consequential principalagent relationship in practice. Each condition may lead to several outcomes, which, when present, influence the participant's willingness to contract. These are now explored:

First, there is "outcome uncertainty", as the industry success of business rescue is punted at approximately 5 per cent (Loubser, 2013) in the US and at 9.4 per cent in South Africa (Pretorius, 2015). With uncertain outcomes, the agent is less willing to contract, especially when the uncertainties originate from mostly external factors.

Second, associated with uncertainty is the "outcome measurability", which is not determinable, as the Act provides for two possibilities, reorganisation (S 128(1)(b) rehabilitation) or pursuing a better return than that in immediate liquidation (S 128(b)(1)iii). The act also provides for compromise (S 155); alternatives such as sales, mergers and takeovers may also be relevant as potential measures of outcome success, as they conserve jobs and benefit the economy (Pretorius, 2015). Outcome measurability that is difficult to define diminishes parties' willingness to contract.

Third, if "task programmability" is low, particularly as in the case of business rescue, then agents are unwilling to contract their behaviour while principals are generally insufficiently informed about the tasks. Pretorius (2013) identified 17 activities culminating in five tasks associated with the BRP. The Act, in S 140, explicitly identifies four broad tasks for the BRP that are all subject to low outcome measurability.

Fourth, the duration of the created relationship in business rescue is relatively short, leaving less opportunity for trust to develop. Longer-term relations tend to function with informal "rules" and behaviours. Complicating this is the fact that banks, as the practice principals, "inherit" the BRP and would prefer not to have such a relationship in the first place. They therefore take a strict stand by withholding their support (as power base) when there is any disagreement.

Finally, while principals want to govern agent behaviour with a contract, they are typically incapable of doing so. In the first place, they are hiring a specialist to optimise expertise. Driven by moral hazard and adverse selection, "contractibility" is vague, as shown in the previous points and in Figure 1. Ultimately, the contract which is the solution to classic agency situations seems not to present a solution during the business rescue. Not only have banks realised that they cannot contract the BRP behaviour, but they also understand that, within the Act, they hold significant powers in the practice principal-agent relationship. Practically - none of the perceived relationships are true agency relationships, despite containing several elements supporting them.

\subsection{Contracting as governance structure in the practice agency relationship}

The cornerstone of agency theory is that the assumption that the interests of principals and agents diverge (Hill \& Jones, 1992), and the proposed solution is contracting as governance structure to address it. Such contracts can be implicit or explicit in describing incentives, monitoring devices, bonding and other forms of social contracting to minimise agency costs (Shapiro, 2005).

As already shown in the boundary conditions and element manifestations, contracting in the practice principal-agent relationship is difficult and the contracting cost to establish it might not 
equal the value gained.

At first glance the differences between the practice principals and the agents may seem to constitute "irreconcilable principle differences", which render it not contractible. However, in order to move forward, these differences must be overcome. Future research should propose alternatives for addressing this impasse.

\section{Implications and recommendations to industry}

First, while Chapter 6 has been dubbed a debtor-friendly regime, comprehension of the legislative tension and its practical outcome points to it instead as de facto creditor-friendly. The perceived principal-agent (Bank-BRP) relationship that takes place in practice, as described in this paper, is clear proof that Chapter 6 is not debtor-friendly. Legally, this relationship does not exist. The disproportionate powers of the banks in the altered agency relationship are cumbersome and, in my opinion, not what the law intended, and they are difficult to regulate.

Second, the results of this study specifically highlight that contracting associated with classic agency relationships appears inadequate to address the conflict. Banks suffer completely adverse selection and have no opportunity of influencing the selection. However, to oppose the BRPs they deem unfit they withhold their support. Loubser (2010) alludes to differences in perception of reasonable prospect, where the goal difference between actors originates (Pretorius, 2014a) as a contentious issue.

The practical value of the research was found mainly in the enhanced understanding of the unintended or unforeseen practical consequences of the act in a debtor-friendly fallacy namely:

What could be achieved by appointing directors? First, these results show that they should not file for rescue despite being compelled to file if they experience financial distress. However, as this may constitute reckless trading even though they have no choice, then the best advice is to file much earlier and overcome "denial", potentially by using early detection mechanisms. All the previous research suggests that early action in the face of distress improves the probability of turnaround.

What could BRPs do? First, they should focus on enhanced collaboration, especially when dealing with the banks. Many of the conflict issues identified hinge on the clarity of the BRP intentions to reorganise rather than find a return better than is found in liquidation. The second option, which is related to collaboration, would be to forge close relations with the banks when establishing reasonable prospect. This may also enhance access to information for the BRP. The importance of enhancing skill levels through training for BRPs has also been suggested by banks.

What could creditors do? Banks have the dominant power in the reorganising strategies available to BRPs and they hold several of the "aces" in a rescue. If banks could find ways of assisting the BRPs to overcome their information asymmetry, this could have a dramatic effect on reducing the time it takes to investigate the firm's affairs and reaching a conclusion on the status of reasonable prospect. Banks appear not to appreciate the BRP's tasks in relation to their complexity, the number of tasks or the time limitations, as described by Pretorius (2013). Their focus is their investment in the business, limiting their ability to cooperate (vested interests) with the BRP despite the Act making provision for the functioning of a creditors' committee.

What could the Regulator do? First, the Regulator could investigate amendments to the Act that may alter the exclusive powers of secured creditors in business rescue. Under UK administration, secured creditors are excluded from voting. This research exposed the debilitating powers of the banks, especially in the vote at the second creditors' meeting, where the plan must be supported or rejected for implementation. Second, amendment could consider expanding the use of the creditors' committee and build on adversarial collaboration as a principle. Third, the accreditation of BRPs based on competencies needs to be addressed urgently. In classic agency theory, the assumption is that equal information exists and that it can be addressed by the principals and the agents. However, as shown, this is not the case in business rescue. The Regulator could therefore consider investigating requirements for the creditors to enhance the business process. One of the 
suggestions put forward was that the Regulator should create a litigation fund for BRPs to challenge the banks' actions, thereby testing certain practices and creating case law. Finally, banks also blamed the Regulator for licensing incompetent practitioners. There is thus a need for an improved accreditation process by the Regulator. Some research in this field has been reported by Jacobs (2012) and Pretorius (2013).

\subsection{Implications for theory - a researcher observation}

This research demonstrated three "variants" of the agency dilemma when the context is voluntary filing in business rescue. In comparison with a board-manager or firm-consultant agency relationship, where the principals and agents are clearly identified and stable, with clear hazards and costs, the rescue context results in the creation of different relationships and simultaneously ending the initial relationship between banks and directors governed by the loan contracting. In business rescue, the unique situation occurs where the directors as the believed principals agree, select, appoint and contract with the BRP as agent. Immediately after appointment, the Act empowers the BRP to take full management control and decision-making, which includes the powers over the directors, whose powers diminish completely and result in zero rights, barring the contributing value of their potential vote as shareholder-creditors.

In business rescue, on the appointment of the BRP, a "practice" principal appears, namely, the creditor body, which is driven and controlled by banks as the primary creditors. This body's powers are prescribed in the Act and it functions mainly through the voting interest they have when supporting or opposing the proposed rescue plan (or not). While the BRP can effectively do almost anything until presenting the rescue plan that $\mathrm{s}$ /he must propose, the outcome depends solely on the support of this practice principal. Thus, the bank can indirectly control the actions of the BRP through the threat of removal or support of the plan (or not).

\subsection{Implications for research}

Researchers could benefit from this paper mainly by understanding the complexities created when a business goes into business rescue. Future research should pursue the extension of the creditor committee as a potential avenue to using alternatives like adversarial collaboration or alternative dispute resolution as solutions.

\subsection{Limitations and future research}

Despite data being directly obtained from the primary sources, namely BRPs and bank subjects, the main limitation of this research is my potential bias as auto-ethnographer. I therefore pursued data source triangulation by using narratives, a framework and a comparative table with elements of the classic agency relationship to pursue trustworthiness. Secondly, potential subject bias has also been pointed out, so the results should serve as guideline insights rather than as concrete facts. Member checking also supported the findings and interpretations. The proposed recommendation for an adversarial collaboration process should be considered by the Regulator as a starting point for addressing the potentially debilitating conflict. The proposed solution must therefore be evaluated with this in mind, as other interpretations might have been overlooked. Finally, the perceived relationships described are subject to legal challenge and interpretation. Potentially, court appointments of the BRP may alter how the relationships are perceived, especially from the legal perspective.

Understanding the perceived interrelations between agents and principals is only the starting point in this complex web of issues. Future research should seek specifically to investigate alternative solutions. Identifying and comparing the legally-constituted agency relationship with these quasi relationships could also enlighten the Regulator during amendments to the Act.

\section{Declaration}

The author declares that he has no financial or personal relationship(s) which may have inappropriately influenced him in writing this paper. 


\section{References}

ACT 71. REPUBLIC OF SOUTH AFRICA. 2008. Companies Act 71 of 2008. Government Gazette No 32121 Volume 421. Pretoria: Government Printer.

ANDERSON, L. 2006. Analytic auto ethnography. Journal of Contemporary Ethnography, 35(4):373-395. BERNIKER, E. \& MCNABB, D.E. 2011. Dialectical inquiry: A structured qualitative research method. The Qualitative Report, 11(4):643-664.

BRADSTREET, R., PRETORIUS, M. \& MINDLIN, P. 2014. Business-driven rescue in South Africa: Reorganising mindsets. Conference paper, March. Australia.

BR PORTAL. 2013. Second-generation scenarios for business rescue in South Africa. http://www.brportal.co.za/forum [accessed April 2014].

COLQUIT, J.A. \& ZAPATA-PHELAN, C.P. 2007. Trends in theory building and theory testing: A five decade study of The Academy of Management Journal. Academy of Management Journal, 50(6):1281-1303. DYSON, M. 2007. My story in a profession of stories: Auto-ethnography: An empowering methodology for educators. Australian Journal of Teacher Education, 32(1):35-48.

EISENHARDT, K.M. 1989. Agency theory: An assessment review. The Academy of Management Review, 14(1):57-74.

FAMA, E.F. \& JENSEN, M.C. 1983. Agency problems and residual claims. Journal of Law and Economics, $26(2): 327-349$.

FINE, G.A., MORRILL1, C. \& SURIANARAIN, S. 2009. Ethnography in organizational settings. Published in Buchanan, D.A. \& Bryman, A. (eds.) The Sage handbook of organizational research methods. London: Sage.

GOLD, R.L. 1958. Roles in sociological field observations. Social Forces, 36(3):217-223.

GRIBNITZ, K. \& APPELBAUM, R. 2014. Business rescue and compromise offers: A practical analysis of the obligations and rights as set out in Chapter 6 of the Companies Act No 71 of 2008 as amended. ( $1^{\text {st }}$ ed.) G\&A Compass Publishing (Pty) Limited. $1^{\text {st }}$ Edition.

HILL, C.W.L. \& JONES, T.M. 1992. Stakeholder: Agency theory. Journal of Management Studies, 29(2): 131-153.

JACOBS, L.M. 2012. Die nuwe ondernemingsreddingpraktisyn: Geneesheer of begrafnisondernemer? ' $n$ Ondersoek na die kwalifikasies van die reddingspraktisyn (The new business rescue practitioner: Surgeon or undertaker? An investigation into the qualifications of the rescue practitioner). Litnet Academic, 9(2). http://www.litnet.co.za/Article/die-nuwe-ondernemingsreddingspraktisyn-geneesheer-ofbegrafnisondernemer-n-ondersoek-na [accessed September 2012].

JENSEN, M.C. \& MECKLING, W.H. 1976. The theory of the firm: Managerial behaviour, agency costs and ownership structure. Journal of Economics, 3(4):305-360.

KAHNEMAN, D. 2011. Thinking, fast and slow. New York: Penguin Books.

KULIK, B.W. 2005. Agency theory, reasoning and culture at Enron: In search of a solution. Journal of Business Ethics, 59:347-360.

LUI, A. 2011. Multiple principal-agent problems in securitisation. Poznan University of Economics Review, 11(2):47-71.

LE ROUX, I. \& DUNCAN, K. 2013. The naked truth: Creditor understanding of business rescue: A small business perspective. Southern African Journal of Entrepreneurship and Small Business Management, 6: 57-74.

LOUBSER, A. 2010. The business rescue proceedings in the Companies Act of 2008: Concerns and questions (part 1). TSAR, 3:501-514.

LOUBSER, A. 2013. Tilting at windmills? The quest for an effective corporate rescue procedure in South Africa. Mercantile Law Journal, 25:437-457.

McCLELLAND, D.C. 1998. Identifying competencies with behavioural-element interviews. Psychological Science, 9(5):331-339.

MEHROTRA, V. 2011. Angel agents: What we can (and cannot) learn from Pierre Lefaucheux' stewardship of Regie Renault. Academy of Management Perspectives, 14-20. 
MINDLIN, P. 2013. Comparative analysis of Chapter 6 of the South African Companies Act, No. 71 of 2008 (Business Rescue Proceeding), presentation to the Company Law Symposium, organised by The South Africa Department of Trade and Industry and The Specialist Committee on Company Law, March.

NYBERG, A.J., FULMER, I.S., GERHART, B. \& CARPENTER, M.A. 2010. Agency theory revisited: CEO return and shareholder interest alignment. Academy of Management Journal, 53(5):1024-1049.

PRATT, M.G., ROCKMANN, K.W. \& KAUFMANN, J.B. 2006. Constructing professional identity: The role of work and identity learning cycles in the customization of identity among medical residents. Academy of Management Journal, 49(2):235-262.

PRETORIUS, M. 2013. Tasks and activities of the business rescue practitioner: A strategy as practice approach. South African Business Review, 17(3):1-26.

PRETORIUS, M. 2014a. A competency framework for the business rescue practitioner profession. Acta Commercii, 12(2):87-107.

PRETORIUS, M. 2014b. Addressing principal-agent conflict in business rescue. Presented at the $26^{\text {th }}$ SAIMS conference in Vanderbijl Park, South Africa. 14-17 September, 2014. http://www.saibw.co.za/ docs/Proceedings\%20SAIMS2014.pdf [accessed November 2014].

PRETORIUS, M. 2015. Business rescue status report. Unpublished report presented to the Regulator. December.

PRETORIUS, M. \& HOLTZHAUZEN, G.T.D. 2013. Business rescue decision-making through verifier determinant: Ask the specialists. South African Journal of Economic and Management Sciences, 16(4): 468-485.

SHAPIRO. S.P. 2005. Agency theory. Annual Review of Sociology, 21:263-284.

SMITH, M. \& GRAVES, C. 2005. Corporate turnaround and financial distress. Managerial Auditing Journal, 20(3):304-320.

SNYMAN-VAN DEVENTER, E. \& JACOBS, L. 2014. Corporate rescue: The South African business plan examined. Nottingham Insolvency and Business Law Journal, 2(6):103-115.

TRAHMS, C.A., NDOFOR, H. A. \& SIRMON, D.G. 2013. Organizational decline and turnaround: A review and agenda for future research. Journal of Management, 39:1227-1307.

VENTER, E.R. \& DE VILLIERS, C. 2013. The accounting profession's influence on academe: South African evidence. Accounting, Auditing and Accountability Journal, 26(8): 1246-1278. DOI 10.1108/AAAJ06-2012-01027.

WEYERS, K. \& ELLIOT, A. 2014. Business restructuring and insolvency newsletter. www.hoganlovells.com. (December) [accessed December 2014].

WEBNE-BEHRMAN, H. 2009. Conflict resolution skills - Part 1. http://www.aipc.net.au/ articles/conflictresolution-skills.-part-1/ [accessed March 2015].

WOODSIDE, A.G. 2010. Case study research: Theory, methods, practice. UK: Emerald, Bingley.

YIN, R.K. 2003. Case study research: Design and methods (Applied social research methods $\left(3^{\text {rd }}\right.$ ed.) Applied Social Research Methods Series, 5. London: Sage Publications. 